UN ITED STATES

DEPARTMENT OF THE INTERIOR

GEOLOGICAL SURVEY

DYE-DISPERSION STUDY ON LAKE CHAMPLAIN, NEAR CROWN POINT, NEW YORK

By Paul H. Hamecher and Lloyd A. Wagner

Open-File Report 74-355

Prepared in cooperation with the

New York State Department of Environmental Conservation

Albany, New York

January 1975 


\section{CONTENTS}

\section{Page}

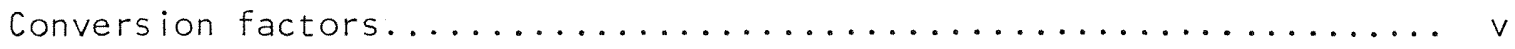

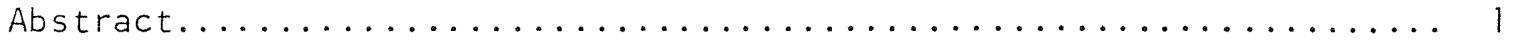

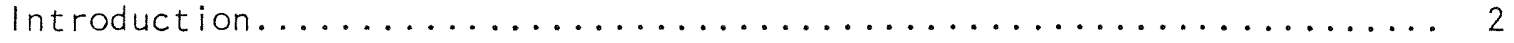

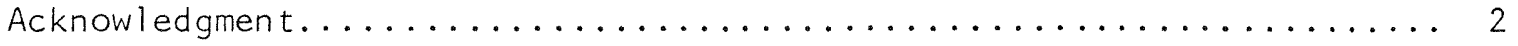

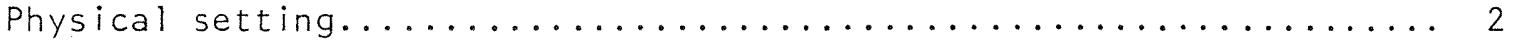

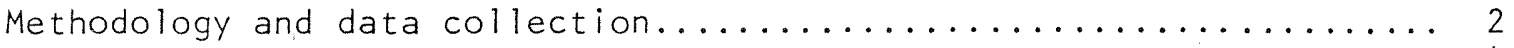

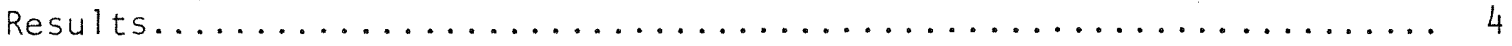

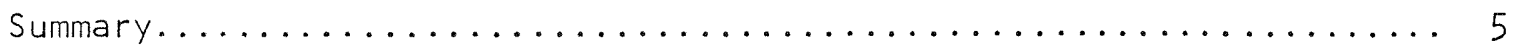

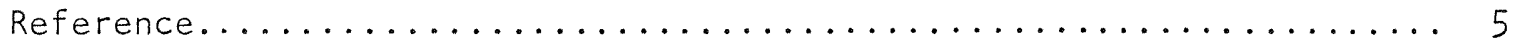




\section{ILLUSTRATIONS \\ (Plates are in pocket)}

Page

Plate 1. Map showing sampling sites on Lake Champlain near diffuser pipe of International Paper Company, October 17 and 18, 1973..

2. Map showing dye concentrations and extent of dye cloud in study area on Lake Champlain near diffuser pipe of International

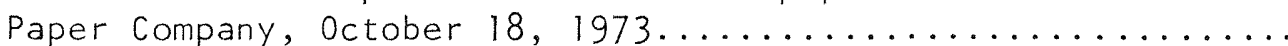

Figure 1. Map showing location of dye-dispersion study on Lake Champlain near diffuser pipe of International Paper Company near Crown Point, N.Y., October 17 and $18,1973 \ldots \ldots \ldots \ldots \ldots \ldots \ldots \ldots$

2. Time-discharge curve for Parshall flume above defoamer tank at International Paper Company near Crown Point, N.Y.,

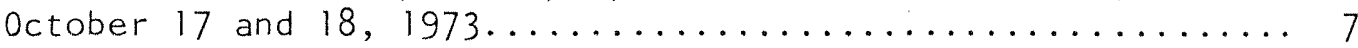

3. Graphs showing concentration of dye at surface plotted against time at sampling sites $A-2$ and $B-2$ on Lake Champlain during dye-dispersion study near diffuser pipe of International

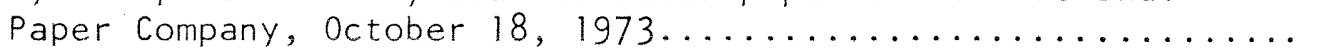

4. Graphs showing concentration of dye at surface plotted against time at sampling sites $\mathrm{C}-2$ and $\mathrm{D}-2$ on Lake Champlain during dye-dispersion study near diffuser pipe of International

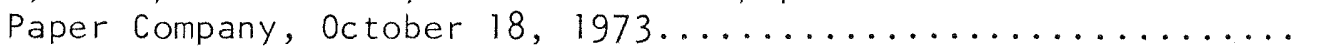

Figures 5-11. Graphs showing dye concentrations in cross sections of Lake Champlain within study area and near diffuser pipe of International Paper Company, October 18, 1973:

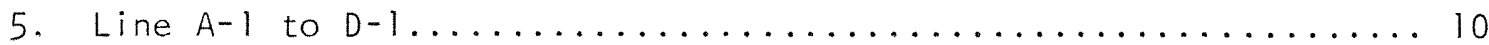

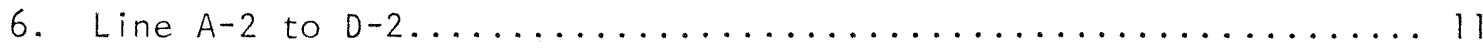

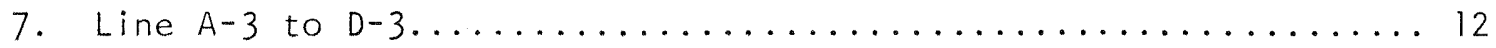

8. Line $A-1$ to $A-3,25 \mathrm{ft}(7.6 \mathrm{~m})$ downstream from diffuser pipe... 13

9. Line $B-1$ to $B-3,100 \mathrm{ft}(30.5 \mathrm{~m})$ downstream from diffuser pipe.. 14

10. Line $\mathrm{C}-1$ to $\mathrm{C}-3,200 \mathrm{ft}(61.0 \mathrm{~m})$ downstream from diffuser pipe.. 15

11. Line $D-1$ to $D-3,400 \mathrm{ft}(122 \mathrm{~m})$ downstream from diffuser pipe... 16 
English units

Volume

\section{Length}

SI units inches (in) $\times 2.540$

feet $(\mathrm{ft}) \times .3048$

miles $(\mathrm{mi}) \times 1.609$
$=$ centimetres $(\mathrm{cm})$

$=$ metres $(\mathrm{m})$

$=$ kilometres $(\mathrm{km})$

\section{Temperature}

degrees Fahrenheit $\left({ }^{\circ} \mathrm{F}\right) \quad\left({ }^{\circ} \mathrm{F}-32\right) 5 / 9=\operatorname{degrees}$ Celsius $\left({ }^{\circ} \mathrm{C}\right)$

\section{Rate of flow}

cubic feet per second $\left(\mathrm{ft}^{3} / \mathrm{s}\right) \times 28.32=$ litres per second $(1 / \mathrm{s})$ cubic feet per second $\left(\mathrm{ft}^{3} / \mathrm{s}\right) \times .02832=$ cubic metres per second $\left(\mathrm{m}^{3} / \mathrm{s}\right)$ gallons per minute $(\mathrm{gal} / \mathrm{min}) \times 3,785=$ millilitres per minute $(\mathrm{ml} / \mathrm{min})$ 


\title{
DYE-DISPERSION STUDY ON LAKE CHAMPLAIN, NEAR CROWN POINT, NEW YORK
}

\section{By}

Paul H. Hamecher and Lloyd A. Wagner

\begin{abstract}
A dye-dispersion study was done near the subsurface diffuser pipe of International Paper Company's waste-treatment plant on Lake Champlain near Crown Point, N.Y., October 18, 1973, to define the dispersion pattern of treated effluent discharged into the lake and to determine the volume of diluted effluent in an area adjacent to the diffuser pipe after a certain period of time. A 20-percent solution of Rhodamine-WT dye was injected into effluent in the Parshall flume at an average rate of 130 millilitres per minute $(0.034$ gallon per minute) for 4 hours. Maximum dye concentration of near-surface samples of water (2 feet below surface) in a 375- $\times$ 800-foot (114- $\times$ 244-metre) rectangle downstream from the diffuser pipe was 32 micrograms per litre. Average depth of the dye-colored water in the rectangle was 12.1 feet (3.69 metres); volume of that water was $3,630,000$ cubic feet $(102,800$ cubic metres). The dispersion patterns (dye clouds) formed by injected dye are outlined on a map of the study area.
\end{abstract}




\section{INTRODUCTION}

This report contains the results of a dye-dispersion study near the subsurface diffuser pipe of International Paper Company's waste-treatment plant on Lake Champlain near Crown Point, N.Y., on October 18, 1973 (fig. 1). The study was done by the U.S. Geological Survey in cooperation with the New York State Department of Environmental Conservation. Purpose of the study was to define the dispersion pattern of treated effluent discharged into the lake and to determine the volume of diluted effluent in an area adjacent to the diffuser pipe after a certain period of time.

Eastern daylight time is used exclusively in this report.

\section{ACKNOWLEDGMENT}

Thanks are extended to the International Paper Company for allowing. access to the waste-treatment plant at their Ticonderoga Mill near Crown Point, N.Y., and for permission to use water levels measured in the Parshall flume on October 17 and 18, 1973.

\section{PHYSICAL SETTING}

The International Paper Company's waste-treatment plant is on the west bank of Lake Champlain, in Essex County, $2 \mathrm{mi}(3 \mathrm{~km})$ south of Crown Point, New York. The study area is on the lake at the outfall-pipe discharge facilities of the treatment plant (fig. l). Treated effluent from the plant is discharged from secondary clarifiers to a Parshall flume and then into a 36-inch- $\left(91-\mathrm{cm}^{-}\right)$diameter pipe that empties into a defoamer tank near the lakeshore. The effluent flows from the defoamer tank through a $42-$ inch- $\left(107-\mathrm{cm}^{-}\right)$diameter pipe that extends $1,642 \mathrm{ft}$ $(500.5 \mathrm{~m})$ into the lake at a depth of about $25 \mathrm{ft}(7.6 \mathrm{~m})$. Attached to the end of the $42-$ inch $(107-\mathrm{cm})$ pipe is $800 \mathrm{ft}(244 \mathrm{~m})$ of 48 -inch$\left(1.22-\mathrm{m}^{-}\right)$diameter diffuser pipe. Effluent is discharged from the diffuser pipe through fifty $6-$ inch- $\left(15-\mathrm{cm}^{-}\right)$diameter ports that are spaced $16 \mathrm{ft}(4.9 \mathrm{~m})$ apart at an angle of 51 degrees from the horizontal. The invert of the diffuser pipe is $70.5 \mathrm{ft}(21.5 \mathrm{~m})$ above mean sea level.

\section{METHODOLOGY AND DATA COLLECTION}

Twelve vertical-profile sampling sites designated $A-1$ to $D-3$ were established in four parallel lines at various distances northwest of the diffuser pipe ( $p l .1)$. These sites were marked with buoys by survey crews from the New York State Department of Environmental Conservation.

A 20-percent solution of Rhodamine-WT dye was continuously injected into the effluent in the Parshall flume at an average rate of $130 \mathrm{ml} / \mathrm{min}$ $(0.034 \mathrm{gal} / \mathrm{min})$ from 1037 hours $(10: 37 \mathrm{a.m.})$ to 1437 hours $(2: 37 \mathrm{p.m.})$ 
on October 18, 1973. A total of 8.2 gal (31 1) of dye was used, and discharge from the Parshall flume ranged from 26.8 to $34.1 \mathrm{ft}^{3} / \mathrm{s}$ (759 to $966 \mathrm{l} / \mathrm{s}$ or 0.759 to $\left.0.966 \mathrm{~m}^{3} / \mathrm{s}\right)^{1}$ (fig. 2). Discharge was computed from recorded water levels in the flume during the 4 hours that dye was injected.

The study area was photographed in color by Walter Fogg of the New York State Department of Environmental Conservation from a helicopter both before and during the dye injection; color slides were prepared. The visual outline of the dye cloud was obtained by projecting the slides onto a base map and adjusting the slide projector until objects in the picture coincided with known points on the base map. The outline of the dye cloud at two different times was drawn on a map (pl. 2) by personnel of the New York State Department of Environmental Conservation.

A Mosely ${ }^{2}$ recorder, connected to a Turner fluorometer equipped with a flow-through door, was used to record the relative values of the fluorescence intensity of Rhodamine-WT dye at 2-ft $(0.6-\mathrm{m})$ intervals in the vertical. The fluorometer had previously been calibrated with solutions of known dye concentration. Dye concentrations near each of the 12 sampling sites $(A-1$ to $D-3)$ were recorded from surface to bottom of lake. Because of wind-drift problems, actual locations of sampling sites differed from the planned locations. Actual locations are plotted in plate 1 as sites 1 through 21 . In addition, the times of day that dye concentrations were recorded at each site are listed in plate 1. Analyses of samples of water taken at 2-ft, vertical intervals at each of the sites were used to prepare a calibration curve. The curve was used to convert readings on the recorder chart to concentrations of dye. Samples of water were taken at the water surface at sites A-2, B-2, C-2, and $D-2$ by four automatic water samplers. Dye concentrations of these samples were later determined in the laboratory. Fluorometer, recorder, analytical, and calibrating procedures are given in a report by wilson (1968).

In addition to the vertical-profile samplings at sites $1-21$ in plate 1, dye concentration $2 \mathrm{ft}(0.6 \mathrm{~m})$ below the water surface was continuously recorded in three traverses (traverse lines 1-3, pl. 1), and water samples were taken for calibrating the recorder chart. Traverse line 1 extended from a point approximately $736 \mathrm{ft}(224 \mathrm{~m})$ southeast of site A-2 to a point approximately $908 \mathrm{ft}(277 \mathrm{~m})$ northwest of site $D-2$; traverse 1 ine 2 extended from a point $392 \mathrm{ft}(119 \mathrm{~m})$ east of $A-3$ to a point $900 \mathrm{ft}(274 \mathrm{~m})$ west of $\mathrm{A}-1$; and traverse line 3 extended from a point $290 \mathrm{ft}(88.4 \mathrm{~m})$ west of $D-1$ to a point $270 \mathrm{ft}(82.3 \mathrm{~m})$ east of $\mathrm{D}-3$. Two onshore transit parties from the New York State Department of Environmental Conservation periodically recorded simultaneous azimuth readings of the boat to define its course or location during the traverse as well as the vertical samplings.

I International Paper Company estimates that the indicated flow may have varied \pm 10 percent.

2 The use of brand names in this report is for identification purposes only and does not imply endorsement by the U.S. Geological Survey. 
During the study, personnel from the New York State Department of Environmental Conservation measured the temperature of the lake water at various depths at the 12 vertical-profile, sampling sites. Temperature was about $12^{\circ} \mathrm{C}$ (Celsius) or $54^{\circ} \mathrm{F}$ (Fahrenheit) at all the sites and at all the depths. Water temperature of the treated effluent at the dye injection site was $27.2^{\circ} \mathrm{C}\left(81^{\circ} \mathrm{F}\right)$.

Lake elevations during the study were obtained periodically from a staff gage set to mean sea level at station " $B$ " in plate 1 . Elevation during the study ranged from 95.54 to $95.62 \mathrm{ft}(29.12$ to $29.14 \mathrm{~m})$ above mean sea level. Wind was the chief cause of the range in elevation.

As illustrated in plate 2, some of the dye moved south from the diffuser pipe during the study period. Floats set at various depths were released by personnel of the New York State Department of Environmental Conservation at several points during the study; movement of floats was traced by the transit parties. The floats, placed at various depths, were made by attaching four one-quarter inch $(0.64 \mathrm{~cm})$ thick by $1 \mathrm{ft}(0.3 \mathrm{~m})$ square aluminum plates to $1-\mathrm{ft}(0.3 \mathrm{~m})$ lengths of wood $2 \times 2$ 's. The floats were attached by cord at different depths to crossed pieces of wood $2 \times 4$ 's that floated on the surface. A small flag was placed at the top of the surface floats. The directions that the floats traveled are shown in plate 1.

\section{RESULTS}

Movement of effluent from the diffuser pipe was readily determined by the dye-injected method. The data show that the dye effluent rises rapidly to the lake surface after emerging from the diffuser pipe before spreading out as a near-surface mass.

Dye concentrations versus time at the water surface (sampling points $A-2, B-2, C-2$, and $D-2$ ) are plotted in figures 3 and 4 . The maximum concentration measured was $30.3 \mathrm{\mu g} / 1$ (micrograms per litre), at sampling site $A-2$.

Dye concentration at about $2 \mathrm{ft}(0.6 \mathrm{~m})$ below the water surface during the three traverses on October 18, 1973, are shown in plate 2 . The maximum concentration measured during the traverses was $32 \mu \mathrm{g} / 1$.

Dye concentration in the vertical samplings for specified times are plotted in figures 5-11. In figures 5-7 the sections are normal to the diffuser pipe; in figures $8-11$ sections are parallel to the diffuser pipe. The maximum dye concentration was $18.2 \mu \mathrm{g} / 1$. The approximate base of the dye concentration $(2 \mu \mathrm{g} / 1)$ is delineated by a line on each figure. This represents the base of the dye dispersion at the time of each sampling, but the base of the plume is assumed to have remained stable during the study.

The volume of water containing Rhodamine-WT dye within the study area (surface area defined by points $A-1, A-3, D-3$, and $D-1$ ) was computed 
to be $3,630,000 \mathrm{ft}^{3}\left(102,800 \mathrm{~m}^{3}\right)$ by the formula $V=L W D$; where length $L=800 \mathrm{ft}(244 \mathrm{~m})$ (distance between 1 ines $A-1$ to $D-1$ and $A-3$ to $D-3$ ), width $W=375 \mathrm{ft}(114 \mathrm{~m})$ (distance between 1 ines $A-1$ to $A-3$ and $D-1$ to $D-3)$, and depth $D=12.1 \mathrm{ft}(3.69 \mathrm{~m})$ (mean depth obtained from the crosssection plots of the depth of water containing Rhodamine-WT dye, figs. 5 to 11$)$.

\section{SUMMARY}

A dye-dispersion study was done near the subsurface diffuser pipe of International Paper Company's waste-treatment plant on Lake Champlain near Crown Point, N.Y., October 18, 1973, to define the dispersion pattern of treated effluent discharged into the lake and to determine the volume of diluted effluent in an area adjacent to the diffuser pipe after a certain period of time. A 20-percent solution of Rhodamine-WT dye was injected into effluent in the Parshall flume at an average rate of $130 \mathrm{ml} / \mathrm{min}(0.034 \mathrm{gal} / \mathrm{min})$ for 4 hours. Maximum dye concentration of near-surface samples of water ( $2 \mathrm{ft}$ below surface) in a $375-\times 800-\mathrm{ft}$ (114- $\times 244-\mathrm{m})$ rectangle downstream from the diffuser pipe was $32 \mu \mathrm{g} / 1$. Average depth of the dye-colored water in the rectangular area was $12.1 \mathrm{ft}(3.69 \mathrm{~m})$; volume of that water was $3,630,000 \mathrm{ft}^{3}\left(102,800 \mathrm{~m}^{3}\right)$. The dispersion patterns (dye clouds) formed by injected dye are outlined on a map of the study area ( $p l .2)$.

\section{REFERENCE}

Wilson, J. F., Jr. 1968, Fluorometric procedures for dye tracing: U.S. Geol. Survey Techniques Water-Resources Inv., book 3, ch. Al2, 31 p. 


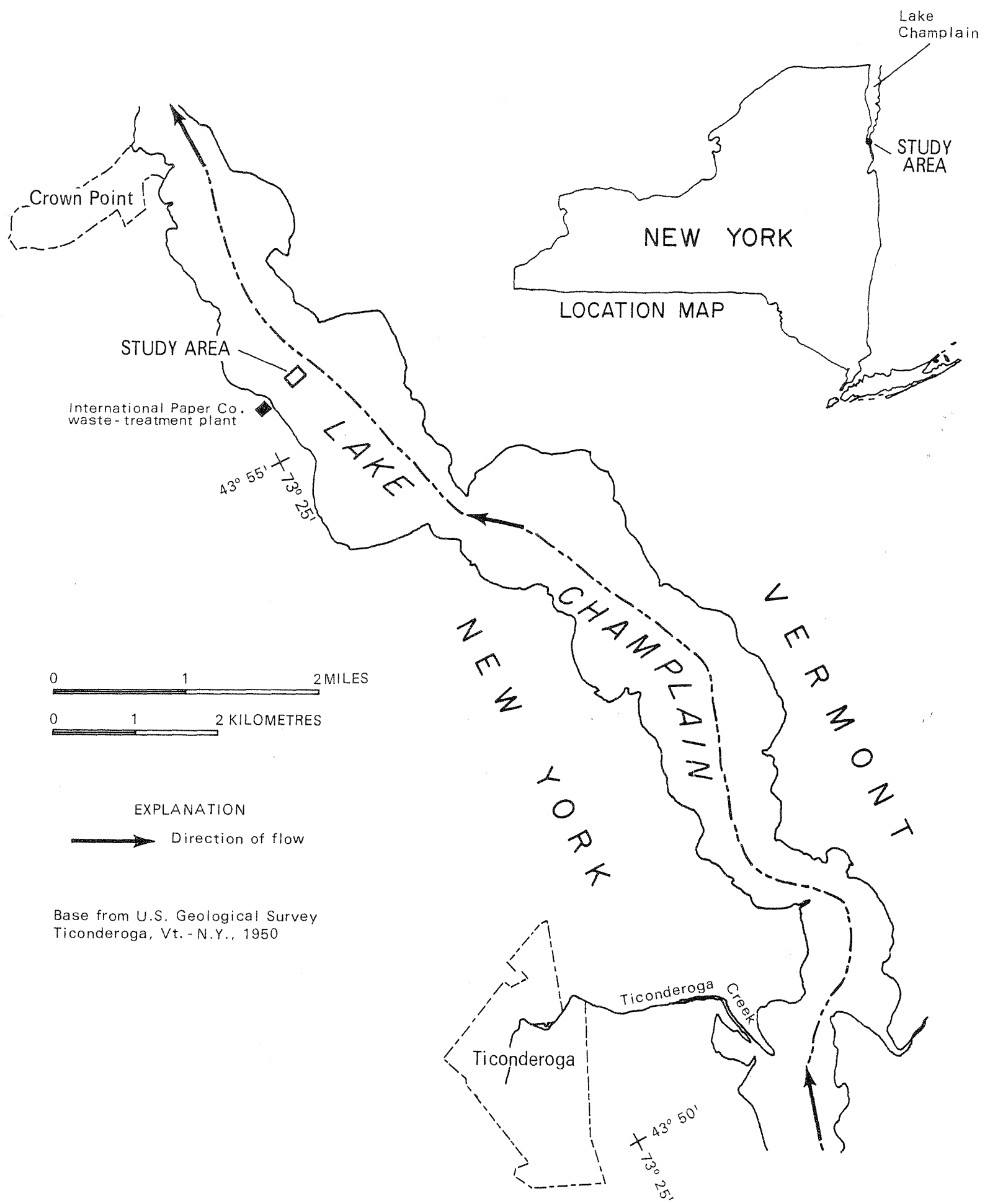

Figure 1.--Location of dye-dispersion study on Lake Champlain near diffuser pipe of International Paper Company near Crown Point, N.Y., October 17 and 18, 1973. 


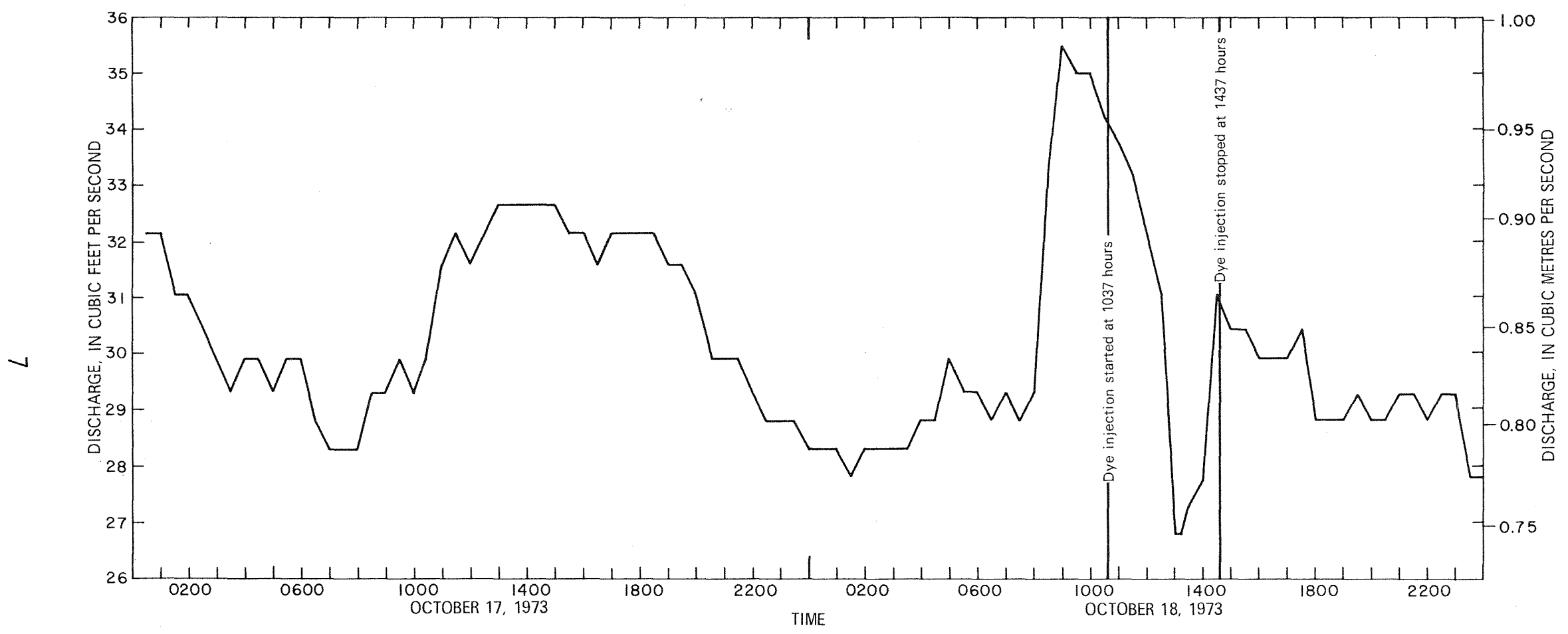

Figure 2.--Time-discharge curve for Parshall flume above defoamer tank at International Paper Company near Crown Point, N.Y., October 17 and 18, 1973. 


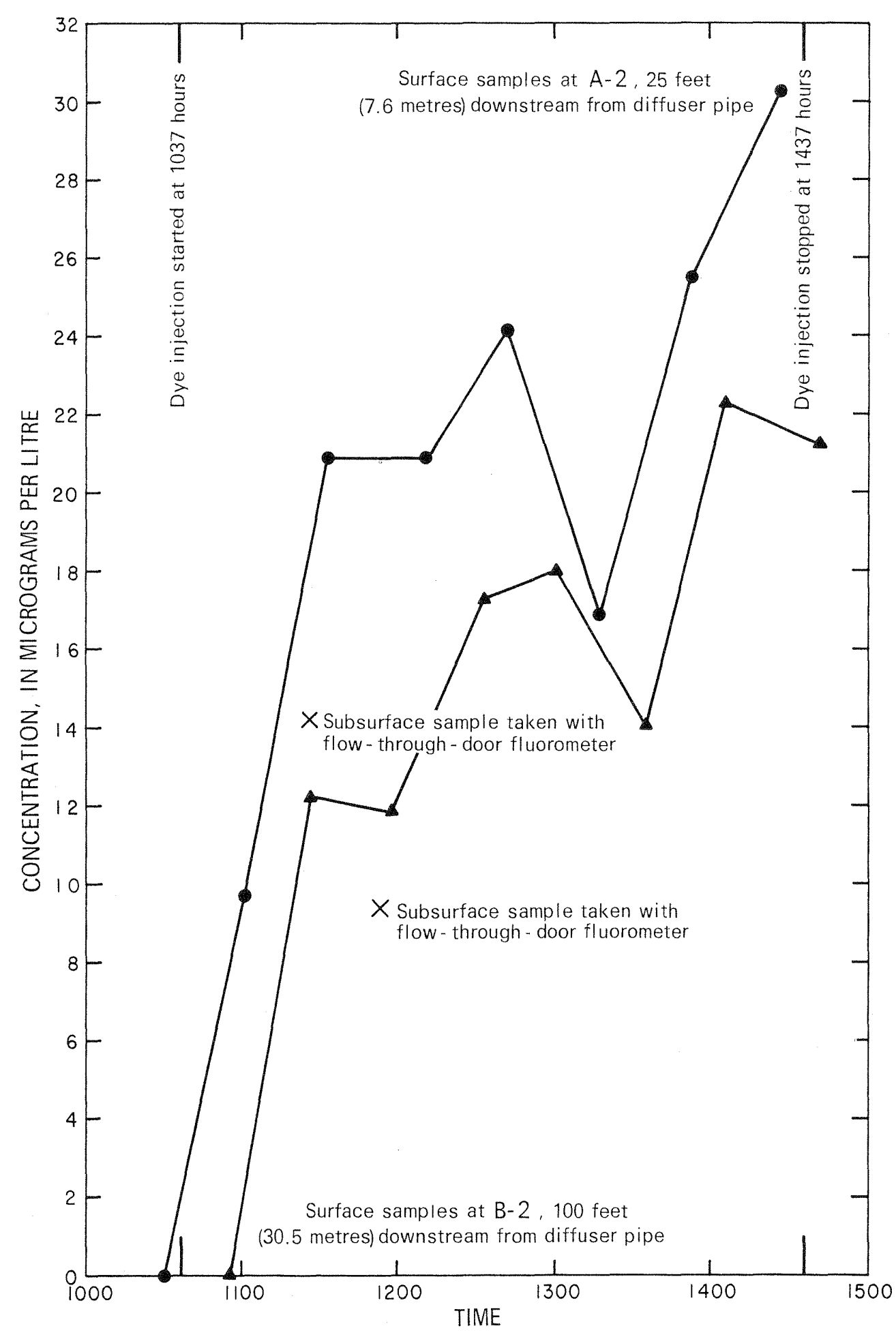

Figure 3.--Concentration of dye at surface plotted against time at sampling sites $A-2$ and $B-2$ on Lake Champlain during dye-dispersion study near diffuser pipe of International Paper Company, October 18, 1973. 


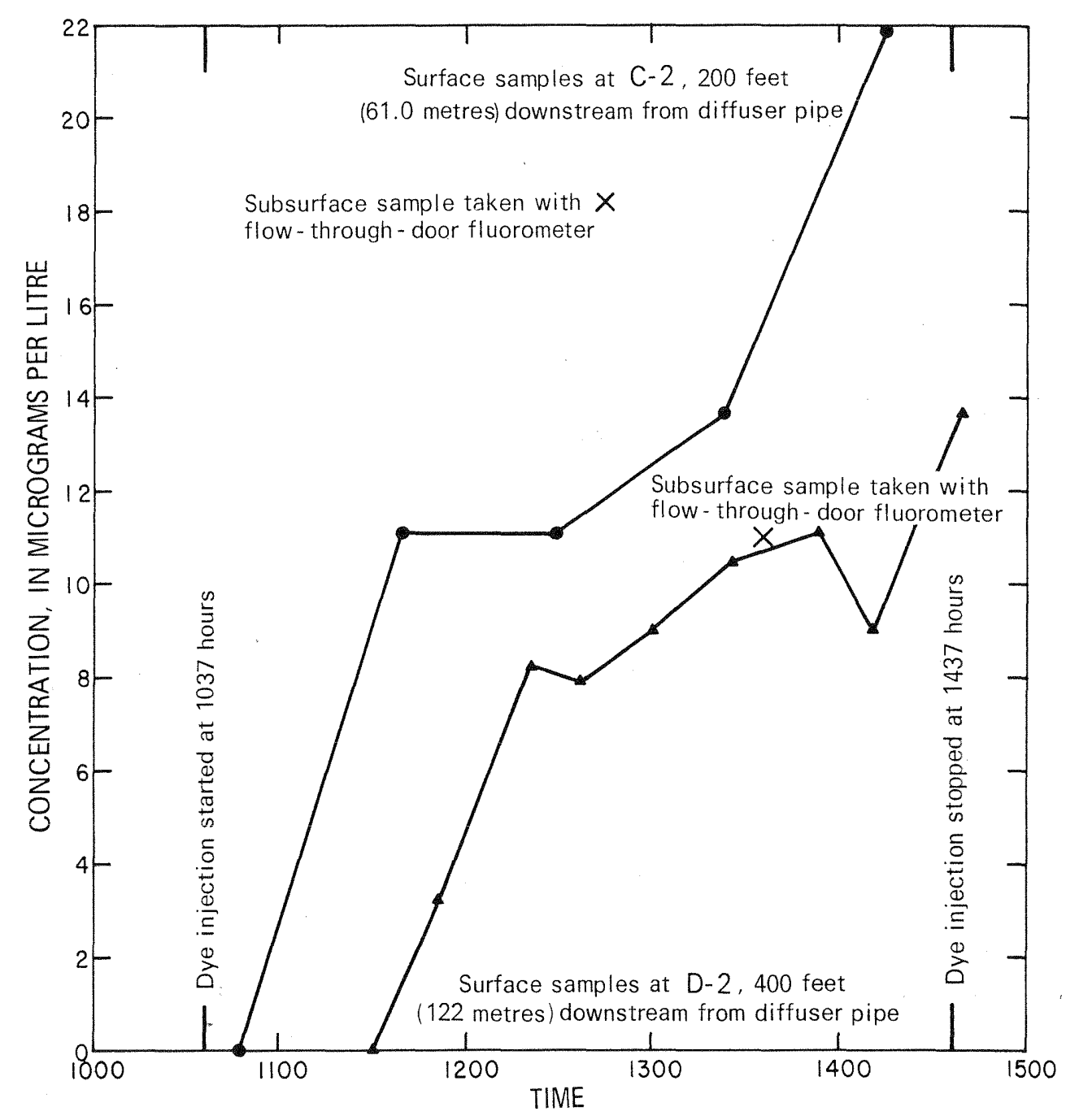

Figure 4.--Concentration of dye at surface plotted against time at sampling sites $\mathrm{C}-2$ and $\mathrm{D}-2$ on Lake Champlain during dye-dispersion study near diffuser pipe of International Paper Company, October 18, 1973. 


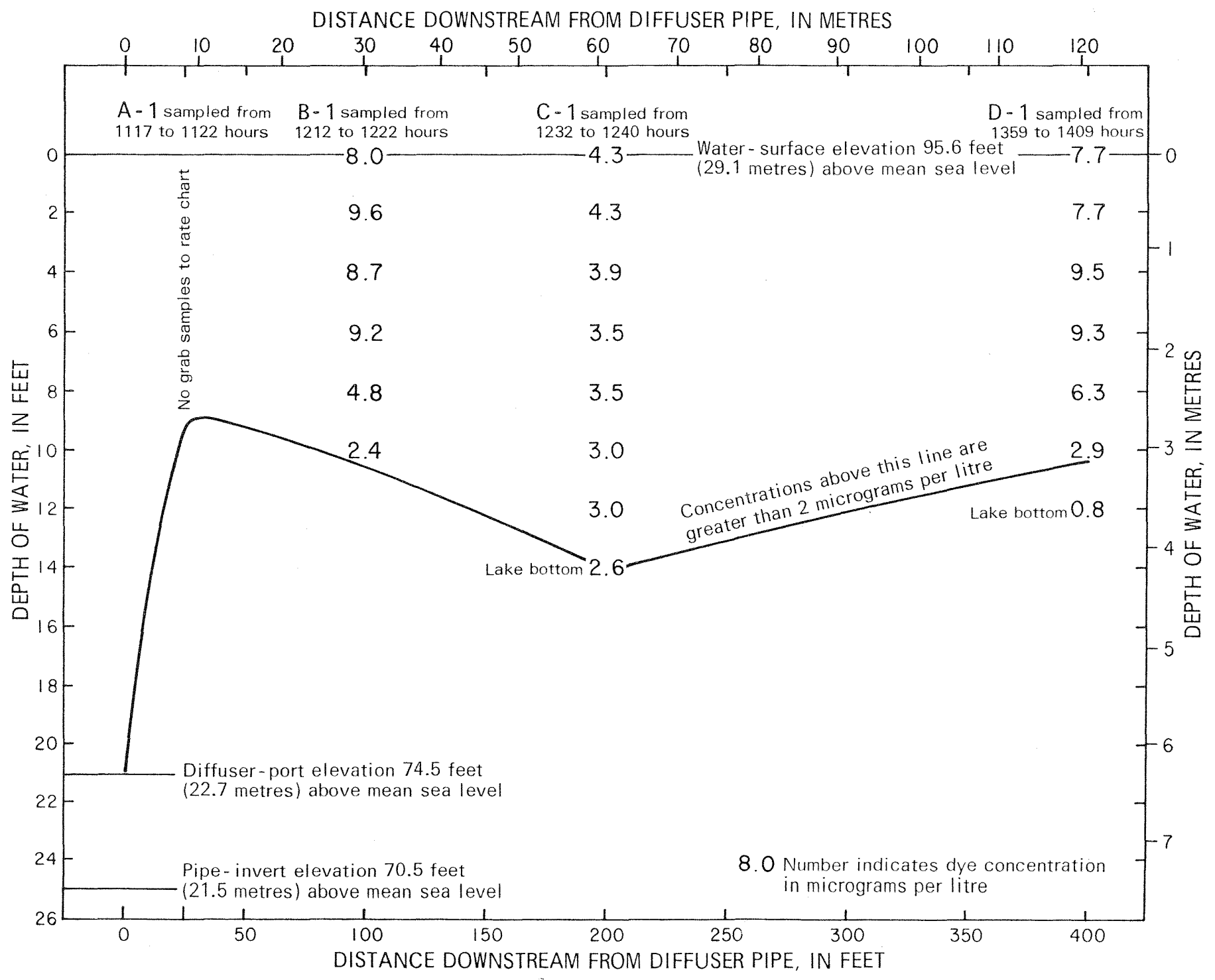

Figure 5.--Dye concentrations in cross section of Lake Champlain within study area and near diffuser pipe of International Paper Company, October 18, 1973, line A-1 to D-1. 


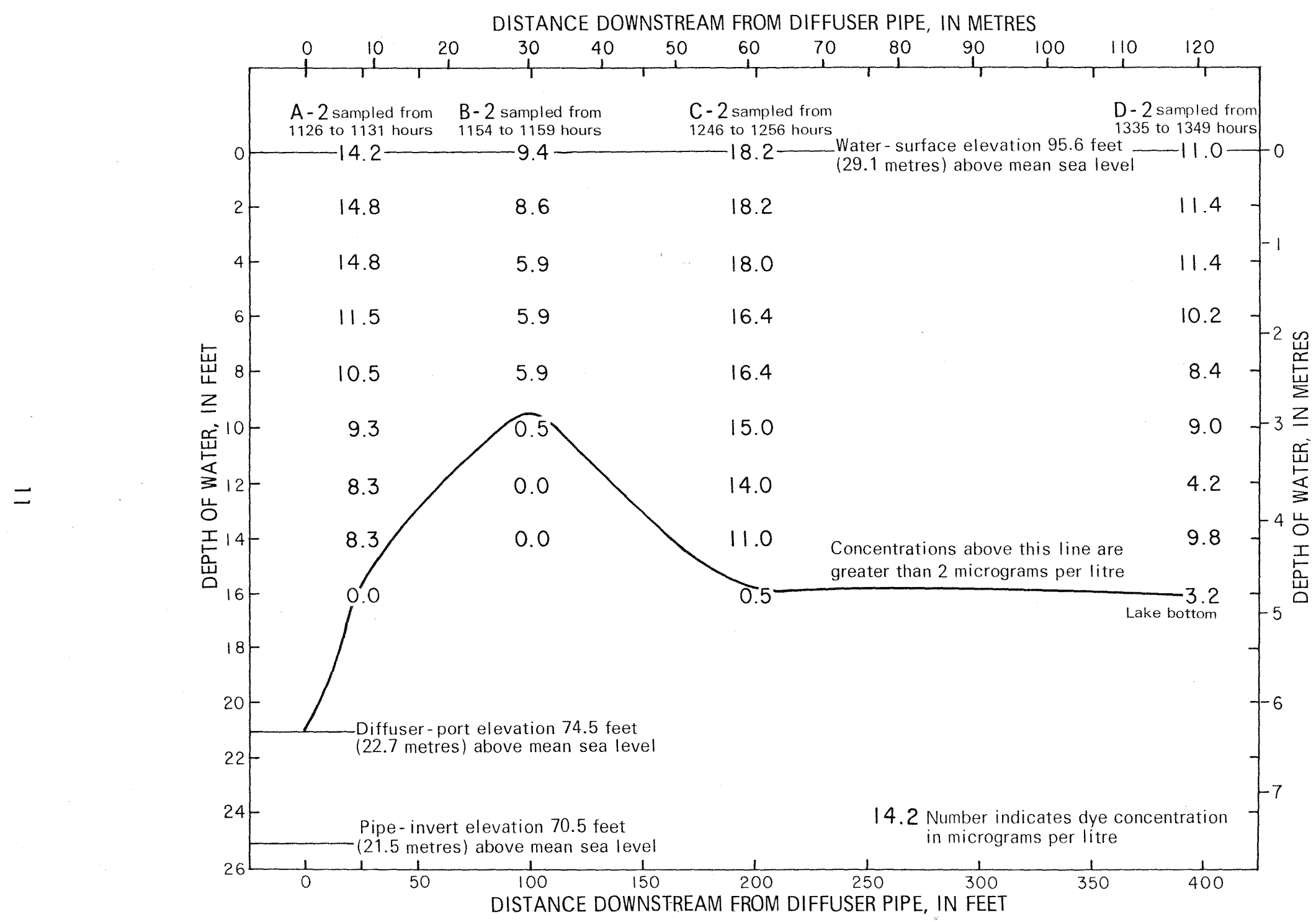

Figure 6.--Dye concentrations in cross section of Lake Champlain within study area and near diffuser pipe of International Paper Company, October 18, 1973, line A-2 to D-2. 


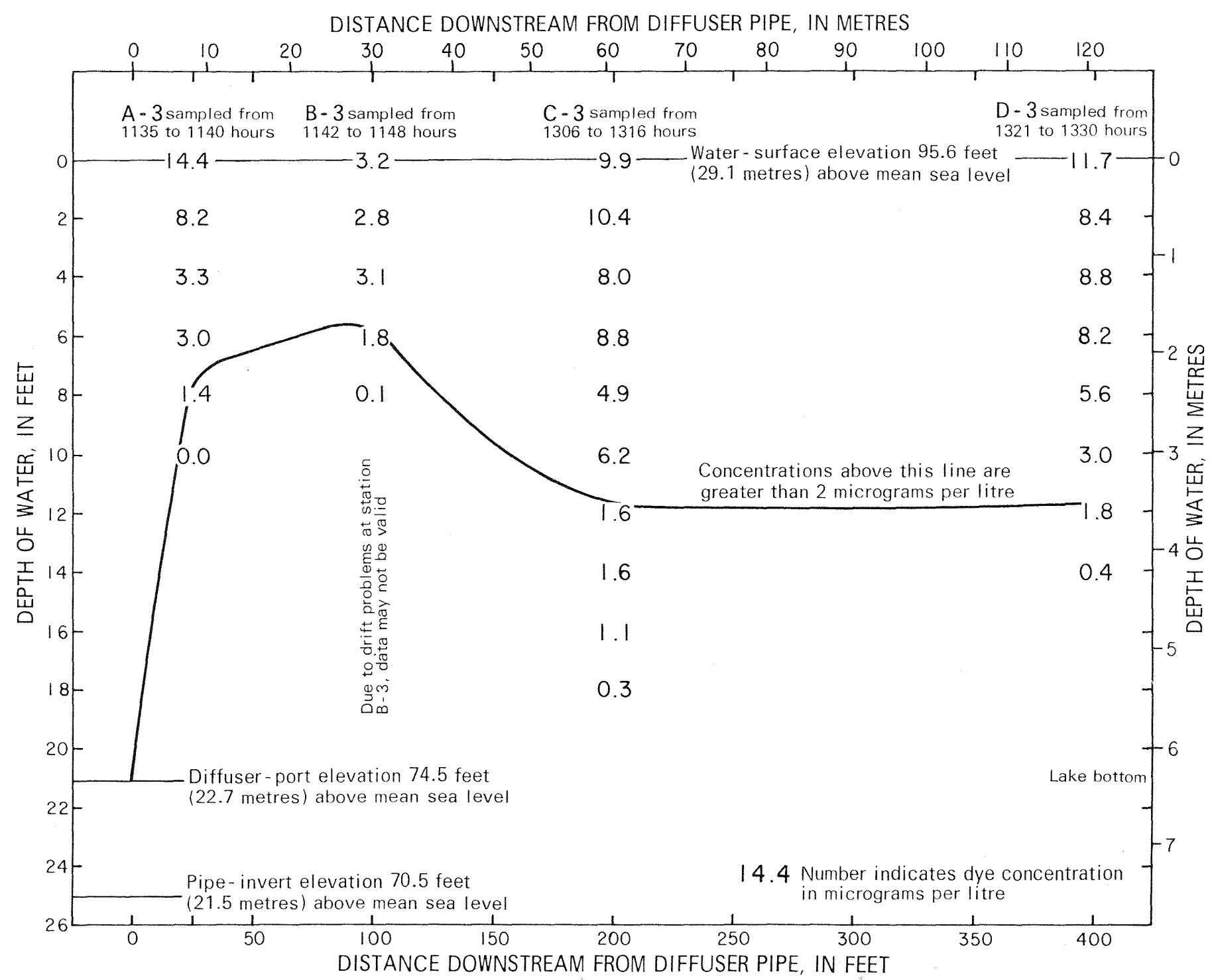

Figure 7.--Dye concentrations in cross section of Lake Champlain within study area and near diffuser pipe of International Paper Company, October 18, 1973, line A-3 to D-3. 


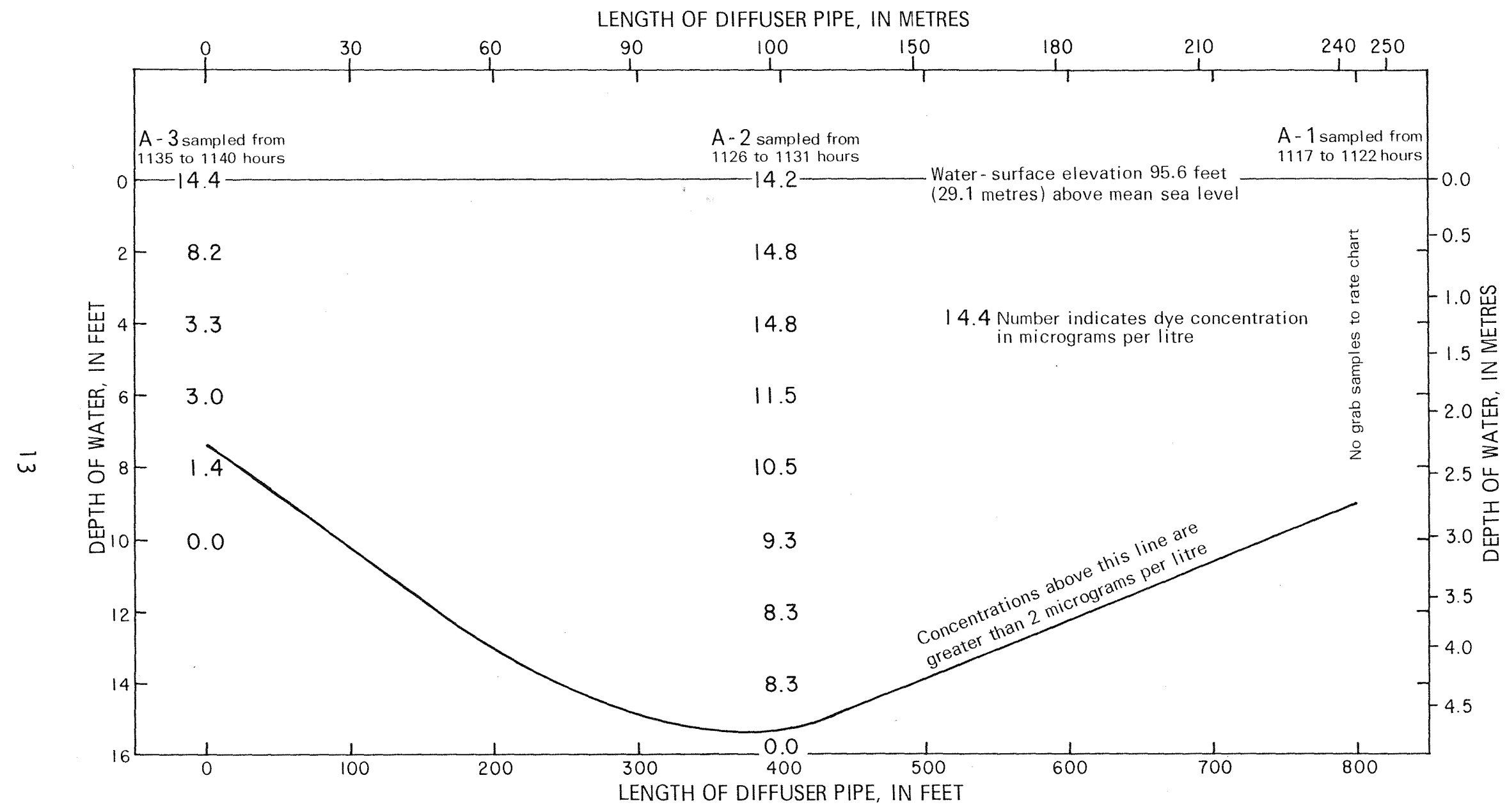

Figure 8.--Dye concentrations in cross section of Lake Champlain within study area and near diffuser pipe of International Paper Company, October 18, 1973, line $A-1$ to $A-3,25 \mathrm{ft}(7.6 \mathrm{~m})$ downstream from diffuser pipe. 


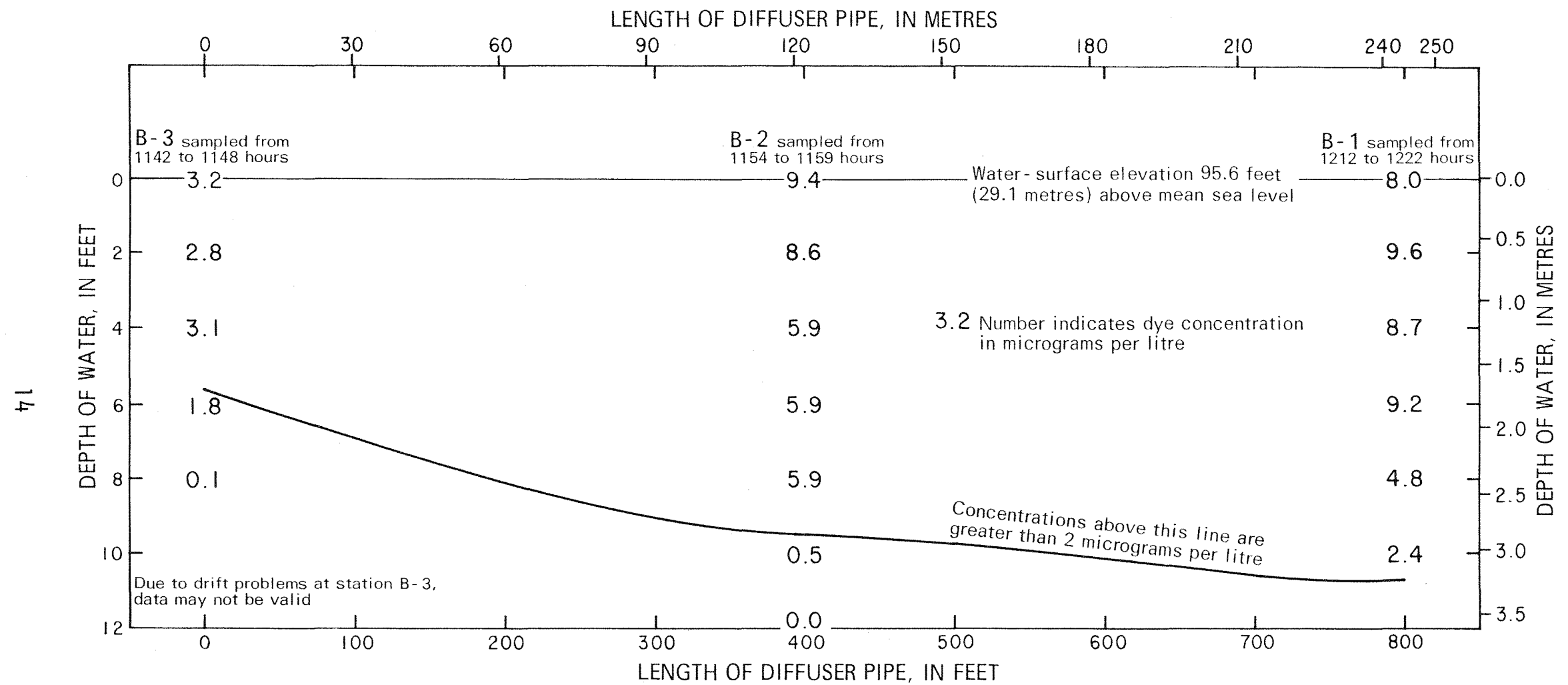

Figure 9.--Dye concentrations in cross section of Lake Champlain within study area and near diffuser pipe of International Paper Company, October 18, 1973, line $B-1$ to $B-3,100 \mathrm{ft}(30.5 \mathrm{~m})$ downstream from diffuser pipe. 


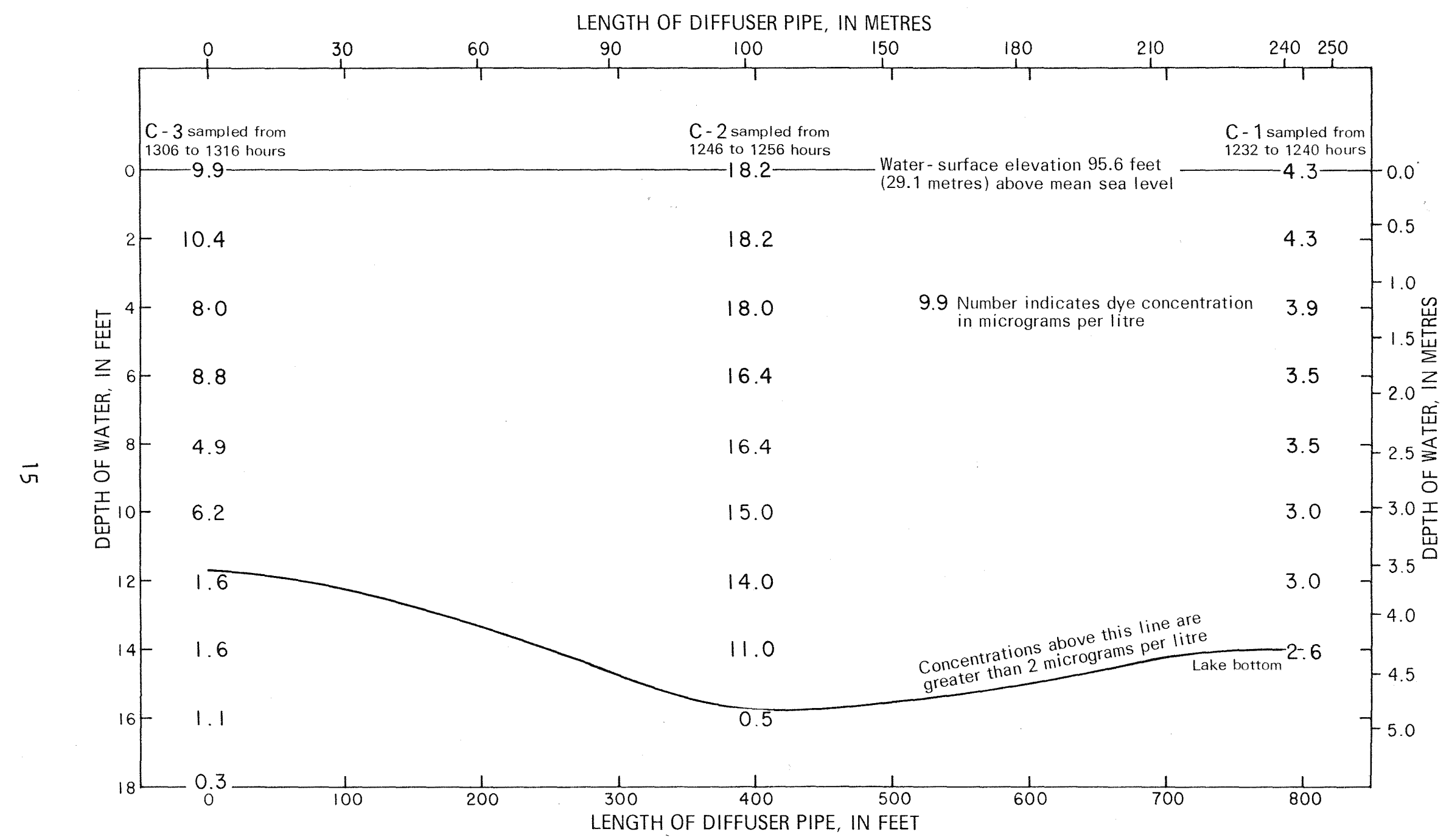

Figure 10.-Dye concentrations in cross section of Lake Champlain within study area and near diffuser pipe of International Paper Company, October 18, 1973, line $\mathrm{C}-1$ to $\mathrm{C}-3,200 \mathrm{ft}(61.0 \mathrm{~m})$ downstream from diffuser pipe. 
LENGTH OF DIFFUSER PIPE, IN METRES

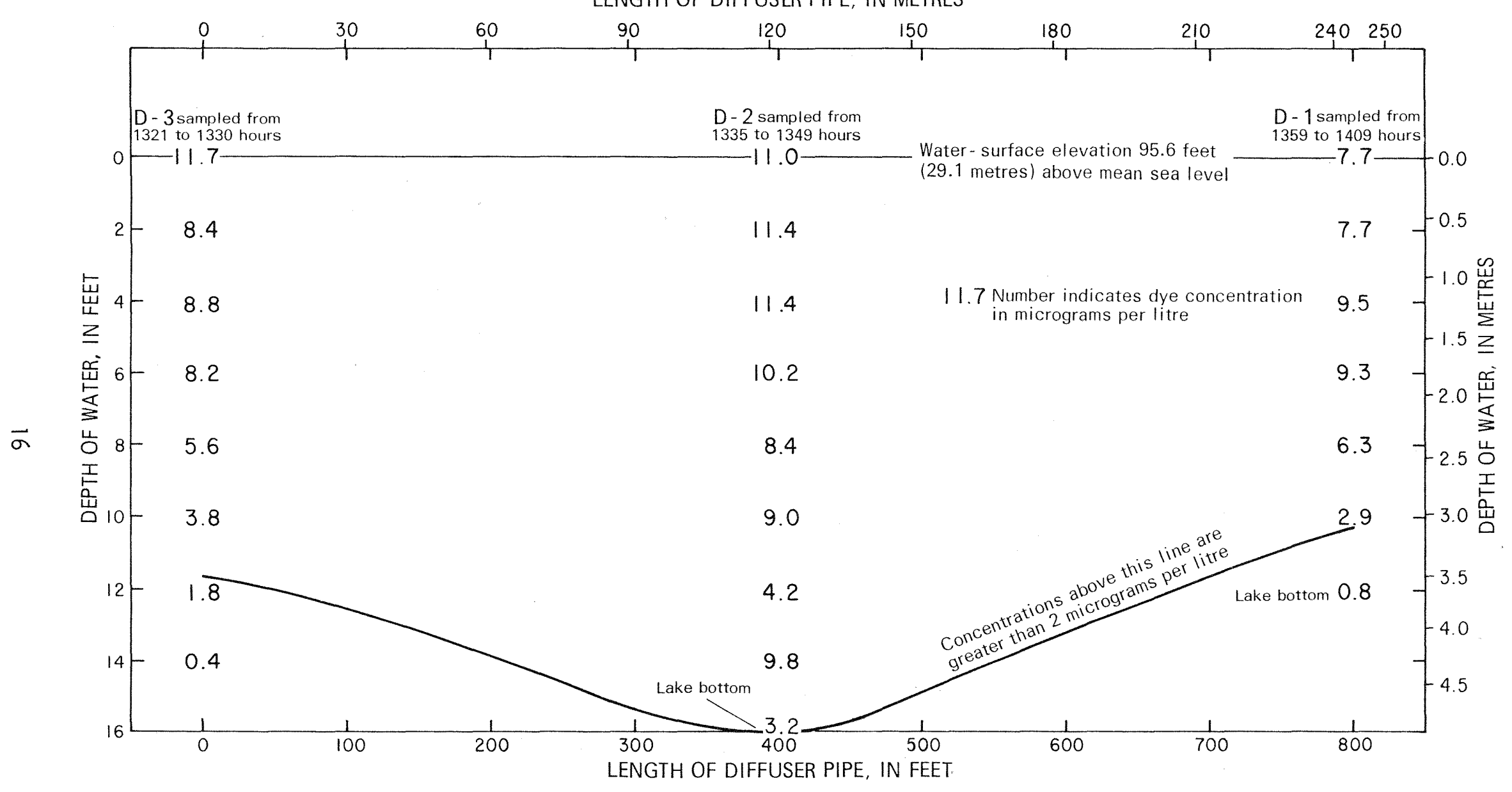

Figure 11.--Dye concentrations in cross section of Lake Champlain within study area and near diffuser pipe of International Paper Company, October 18, 1973,

line $D-1$ to $D-3,400 \mathrm{ft}(122 \mathrm{~m})$ downstream from diffuser pipe. 